\title{
Domesticated Eurocrats: Bureaucratic Discretion in the Legislative Pre-Negotiations of the European Union
}

\author{
Gerald Schneider and Konstantin Baltz \\ Department of Politics and Management, University of Konstanz, Box D 86, Konstanz D-78457, \\ Swizerland. \\ E-mail: gerald.schneider@uni-konstanz.de, konstantin.baltz@uni-konstanz.de
}

This article examines the discretionary power of national governments in EU policy making, focusing on the preparatory stage of European legislation. We assess the conditions under which the ministry in charge of the pre-negotiations is able to withstand attempts of domestic stakeholders to change the national bargaining stance. Our case studies and multivariate regressions on 15 legislative proposals show that the overall conflict between domestic stakeholders and pressure from powerful interest groups make such changes more likely. Parliamentary actors and parties do, conversely, not possess much power in these often technical deliberations. Although governments and their bureaucracies have to yield in some situations, they possess ample discretion in the average decision-making process. We illustrate our findings with a comparative case study on the controversial attempt by the Commission to regulate the usage of PVC softeners in toys.

Acta Politica (2005) 40, 1-27. doi:10.1057/palgrave.ap.5500092

Keywords: agenda setting; European Union; delegation; interest groups; bureaucratic discretion; Council of Ministers

\section{Introduction}

Conservative observers of the integration process often maintain that bureaucratic and government discretion amounts to a major problem. Vaubel (1994) believes that governments and supranational agents engage into 'collusive' behaviour and advance their own interests to the detriment of the electorate. Some EU-sceptics even suspect that bureaucrats push for the establishment of a 'super-state' (e.g. Gillingham, 2003). They perceive the occasional regulatory rigour of the European Commission as a sign that 'Europe has gone too far', as Alesina and Wacziarg (1999) famously put it. Siedentop (2001) accuse the 'eurocrats' of running an increasingly despotic regime. Although most EU-sceptics would like to tame the European 'mandarins', few systematic studies on the use and abuse of bureaucratic 
power exist. Frey $(1997,120)$ complains more generally that the public choice literature 'is rather mute on the question of how the employees in an international organization use the leeway accorded to them'.

This article is an attempt to put the debate on bureaucratic discretion in EU politics on a solid empirical footing. While most extant research analyses the leeway, the European Commission enjoys in its interactions with the Council of Ministers (e.g. Franchino, 2000), our study focuses on the negotiations that a legislative proposal by the European Commission initiates in the member states. These discussions precede the legislative bargaining at the supranational level of decision making. We examine whether domestic stakeholders constrain the responsible government actors during the formation of a national negotiation stance. To put it differently, this article evaluates how much latitude the ministry in charge of a proposal has in its interactions with public and private actors. Our study compares the relative power of government actors with interest groups, parties and the parliament for four member states: Finland, Germany, the Netherlands and the United Kingdom. The literature on interest intermediation has classified these systems quite differently and suspects that the discretion of government agents varies considerably (Baltz et al., 2005).

Our results indicate in accordance with our hypotheses that the lead ministries have to give in when they face powerful private actors and when the preferences of the stakeholders become more heterogeneous. We particularly identify a disproportional power of specialized interest and clientelist networks. Governments are only able to push through their own agenda or to compensate general interest groups if no vested interests are at stake.

The remainder of the article introduces first the main arguments that have been developed to analyse the relationship between the bureaucracy and social actors in the European Union and elsewhere. We will outline the research design and the data set on which we rely in the subsequent section. Next, we estimate government discretion in EU legislation and present some illustrative evidence from a representative legislative proposal. The conclusion offers a critical summary of the results.

\section{Principal-agent Relationships in EU Policy Making}

Moravcsik (1998, 475-476) claims in his study of intergovernmental negotiations that domestic interests decisively shape the bargaining stances of the leading member states: 'On not a single major issue did governments take a position openly opposed by a major peak industrial, financial, or agricultural interest group'. This article examines this conjecture and studies the conditions under which governments give in to the pressure from domestic actors. Our 
study complements a growing literature that makes use of principal agent models to study delegation in the European Union. In the view of the most recent studies, the Commission acts as an agent on behalf of the member states and has to respect the views of these multiple principals at least to some extent. Franchino (2000), for instance, shows in this vein that the amount of conflict and uncertainty that a piece of legislation generates largely determines how much power the Commission receives at the comitology stage of the decision-making process. As the literature on 'two-level' games additionally demonstrates, conservative stakeholders shape the bargaining stances that governments adopt in intergovernmental negotiations of the European Council (Schneider and Cederman, 1994; Hug and König, 2002). Pahre (1997) identifies for the legislative domain the conditions under which national parliaments limit the sway of their governments in the negotiations within the Council of Ministers. Martin (2000) additionally believes that powerful legislatures back home make governments more powerful negotiators. Franchino and Rahming (2003) show similarly that the ideological composition of the Fisheries Council shapes decisions on the allowable catch.

We believe that a principal-agent framework is also appropriate for the study of the domestic pre-negotiations on legislative proposals by the European Commission. Our study follows a rich research tradition that originated from Niskanen's (1971, see also Wintrobe, 1997) model of administrative decision making and more recent attempts to explain the leeway granted to the US bureaucracy and executive branch (e.g. McCubbins et al., 1987, Hammond and Knott, 1996). Some comparativists have followed this lead and demonstrated how parliaments constrain the regulatory activism of governments and their bureaucracies (e.g. Huber and Shipan, 2002).

This application refers to the domestic pre-negotiations of proposals that the European Commission has made. In EU policy making, a single agent often acts on behalf of multiple principals. An illustrative example is the relationship between the Commission and the member states. If the principals disagree, the power of the Commission grows. A similar constellation structures the prenegotiations on EU legislative projects where a lead ministry faces the conflicting expectations of a host of actors, ranging from other government agencies to parties and interest groups.

The principal-agent framework that guides our research effort enables us to answer a double question. First, in what situations are governments able to withstand pressure from stakeholders? Second, which actor group is particularly influential in limiting the sway of governments and thus can be viewed as the dominant principal in this relationship? Perceiving these prenegotiations as a largely informal process, we distinguish between three general 
approaches to explain how much the lead ministry has to yield to the wishes of its domestic principals before the negotiations in the Council of Ministers.

The first theoretical strand argues at the macro-level of analysis and believes that the distribution of preferences drives the conflict between agents (Esteban and Ray, 1999). A second and largely descriptive literature focuses on the importance that other ministries, parties and parliamentary actors play in the 'national coordination of EU policy', as one monograph is called (Kassim et al., 2000; see also Thurner and Stoiber, 2002). A third strand examines how interest groups influence the negotiation stance of governments (Baltz et al., 2004, Schneider and Baltz, 2003a, b).

\section{Preference distribution}

Bargaining theories of European integration most often refer to varying preference configurations to account for the outcome of decision-making processes. Intergovernmental theories play a particularly prominent role (Moravcsik, 1998). They stress that preference diversity negatively affects the process of European integration. Lead ministries, which represent the national governments in the Council of Ministers, should accordingly be able to profit from an absence of conflict among stakeholders. The literature on interest intermediation supports this conjecture. It expects that the variance of the actor positions is smaller in a neo-corporatist in comparison to a pluralist setting and that governments are powerful actors in the former but not in the latter system (Baltz et al., 2004).

Hypothesis 1 summarizes the conjecture that the distribution of preferences affects the relative power of the lead ministry. Note, however, that there are at least two different and complementary ways of using the preference distribution as an indicator of conflict between stakeholders. One important dimension of conflict refers simply to the distribution of preferences, a second, and more precise one, to the shape of this distribution. ${ }^{1}$ We start out with a hypothesis on the variance of the preferences.

H1: The larger the variance of the preference distribution among stakeholders, the more likely it is that the lead ministry has to change its position.

We would expect that stakeholders limit the agenda setting power of a relatively radical lead ministry. Yet, to correlate the position of the lead ministry with its success is no panacea. Barry (1980) has famously argued that to cast the decisive vote just amounts to luck in many instances. This is why we rather look at the overall level of conflict among all stakeholders. Esteban and Ray (1999) show formally that social conflict is most likely under a bimodal distribution of preferences. This assertion receives some support in conflict 
research (e.g. Montalvo and Reynal-Querol, 2003), but has, to our knowledge, never been applied to negotiation analysis. ${ }^{2}$

A high polarization on an issue means that the agenda setting agent is a member of one of the contending coalitions. In cases with a lower polarization, the lead ministry is closer to a majority of all other stakeholders and should therefore be in a more favourable position to shield its interests against the pressure from the other actors.

$\mathrm{H} 2$ : The more polarized the stakeholder positions are, the more likely it is that the lead ministry yields.

Because the Commission makes a first proposal in the domestic prenegotiations, it influences the decision-making processes indirectly. Countries in which most stakeholders are integration sceptical will not experience a lot of conflict. Since the domestic actors are relatively united in their resistance against the legislative goals of the supranational actor, the ministry in charge consequently possesses ample discretion in these member states. As there are differences between the four member states in their general attitude towards integration, we will control for this country level influence in each of the three models we test.

H3: The more integration prone a country is, the less discretion does the lead ministry possess.

\section{State conflict model}

Most countries follow the rule that the wishes of the lead ministry are respected. In Germany, the term Ressortprinzip - the principle to respect the wishes of the department in charge - summarizes this tendency. Intensive informal coordination which is in the view of Derlien $(2000,59)$ a 'core element of German administrative culture' helps to achieve this goal. If a proposal is, however, new or heavily politicized, other departments will also have their say. Dutch foreign policy decisions are made in a similar fashion. Gallhofer et al. (1994; see also Gallhofer and Saris, 1996) show that the ministry in charge is often able to get its will, while decisions tend to be postponed in case of conflict.

Delay is, however, not a real option in the domestic pre-negotiations, as the EU sets the timetable. Lead ministries have thus to react to the opposition from governmental and from private actors in a more active manner. The power of the bureaucracy is in this perspective again a consequence of the amount of conflict a legislative proposal generates.

Resistance against a proposal cannot the least stem from other government actors than the lead ministry. The first aspect that we would like to consider 
here is the impact that the pecking order of the ministries has on the discretion of the lead ministries. As the ministries are not equally endowed with human, financial and political resources, the most powerful government departments might be better able to protect their initial position.

H4: The more powerful the lead ministry is vis-à-vis other state actors with differing positions, the less likely it is that it has to yield during the prenegotiations.

If the lead ministries face opposition from their formal principals, the national legislatures and the political parties sitting in them, their abilities to set the agenda should shrink. The role parliaments play in the domestic pre-negotiations varies considerably across the member states, as the comparative evaluation of Bergman (1997; see also Bailer and Schneider, forthcoming) shows. Even though the European affairs committees are considerably empowered in some member states like Denmark (Bergman, 1997; Pahre, 1997; Pedersen, 2000), they are only able to play a symbolic role in other states. Although these institutional differences are vast, the legislatures and their committees should only matter if their ideological composition deviates substantially from the one of the government (Pahre, 1997, Bailer and Schneider, forthcoming). In this article, we examine whether the lead ministry has to give in if a party or a parliamentary actor utters an opinion on a legislative proposal.

H5: The lead ministry is more likely to yield during the domestic prenegotiations if its initial bargaining stance faces the opposition from parliamentary actors and parties.

\section{Lobbying models}

Most research on the role interest groups play in the European Union is at a highly aggregate level of analysis, pitting 'neo-corporatist' and 'pluralist' systems of interest intermediation against each other. This literature abounds with attempts to classify sectoral and national systems of interest intermediations. Siaroff (1999), for instance, identified 23 different rankings. Previous research has shown that it is almost impossible to classify at the state or even the policy level the way in which private and state actors interact with each other into general categories (Baltz et al., 2004). It seems therefore rather more promising to assume that each legislative proposal and contentious issue leads to a different preference configuration. We will explore in the following especially whether interest groups are able to exert influence in domestic prenegotiations. A first consideration is how powerful these private actors are vis$\grave{a}$-vis the government. 
H6: The more powerful the non-governmental actors in conflict with the lead ministry are, the more likely is that the lead ministry will move away from its initial position.

To influence the negotiation process, interest groups can rely on a variety of means. An increasingly important possibility at the EU level is 'outside lobbying' and thus the activation of the general public through a campaign (Beyers, 2004). We will examine for the domestic pre-negotiations whether or not the usage of this instrument will move the lead department away from its initial bargaining stance. Note however that the reliance on 'voice' strategies such as outside lobbying could also be a consequence of a lack of power. As Hirschman (1970) has shown in a classic study, the relationship between public opposition and other forms to express dissatisfaction is complex. It could thus be that outside lobbying is only effective if a powerful agent exerts it.

H7: If the lead ministry faces voice strategies ('outside lobbying'), it is more probable that it will give up its bargaining position.

In their game-theoretic analysis, Grossman and Helpman (2001, 121-138) show that it is in general easier for policy makers to shield themselves against lobbying efforts if the preference distribution of the interest groups shows a socalled 'opposite' rather than 'like' bias. Opposite bias means that the activated groups are situated both on the left and right of the government; like bias, by contrast, stands for a situation in which the groups are united in their opposition against the government proposal. Yet, similar-minded governments are only credible if they show some moderation. Krishna and Morgan (2001) show (see also Grossman and Helpman, 2001, 130, 133) in this vein that the relationship should hold only if the preferences of the interest groups are not too extreme. This means technically that the relationship between positions and influence should be curvilinear.

H8: The lead ministry is more likely to give in to pressure from interest groups if their preferences are concentrated on one side of the government rather than situated to its left and right.

\section{Research Design and Data Set}

This article examines the constraints a lead ministry faces when it proposes a national bargaining position on legislative projects of the European Union. We assess the likelihood that a government has to give in during the domestic prenegotiations. Yielding to domestic stakeholders, be they other ministries, the parliament or interest groups, is equivalent to giving up the initial proposal. We have gained this indicator and the other measures used in the empirical 
part from the National Decision Making in the European Union data set (NDEU). This data set contains detailed information on 15 legislative proposals the European Commission initiated and that were subsequently submitted to the member states for consideration. The NDEU cases refer to a larger sample of around 70 legislative proposals that are fully analysed in Thomson et al. (forthcoming) and Stokman and Thomson (2004). ${ }^{3}$ This Decision Making in the European Union data set (DEU) is a stratified sample of the legislative proposals of the European Commission from 1997 to 2000. Several criteria guided the inclusion of legislative proposals within the DEU and NDEU data sets. First, the sample had to represent the variety of legislative procedures within the European Union. Second, the proposals had to be sufficiently controversial to be included. ${ }^{4}$ Third, the main fields of legislation had to be covered. This last criterion had the effect that the 15 proposals we examine here cover very different policy areas, reaching from health over consumer to fishery policy. We differentiate the 15 proposals listed in Table $1^{5}$ by considering what kind of legislative procedure they were subject to at the European level and how high the majority threshold in the European Union was. We also include the outcomes. With the exception of two cases, all proposals have been adopted so far.

We relied on expert interviews and secondary sources to gather the decisionmaking data. Four collaborators from the University of Konstanz were sent to the capitals of the four member-states to conduct structured in-depth interviews with policy experts. The research assistants had asked them prior to their travel whether or not they possess a sufficiently broad knowledge on the domestic negotiations preceding the interactions within the Council of Ministers. Each expert - one per proposal in each member state - had to possess detailed information about the domestic prenegotiations on the respective proposal in the member state he or she was asked about. Most of the experts came from the national bureaucracies or from non-state organizations that made part of the domestic pre-negotiations. First the experts identified the controversial issues within a proposal. Our research teams then asked them to name the actors that became active within the decision-making process. They also had to locate the ideal points of these stakeholders on each issue and the final position of the ministry in charge of the pre-negotiations. If it was possible, they had to situate the reference point (the outcome chosen in case the piece of legislation is not accepted) and the saliency each actor attributed to a proposal.

To render the proposals comparable, we normalized all actor positions, their power and the possible outcomes on all issues of each legislative proposal on scales ranging from 0 to 100 . Hence, the underlying assumption of the research endeavour is that we can represent policy conflict spatially. This article examines the likelihood that the lead ministry moves away from its initial 
Table 1 Summary information on the legislative cases included in our analysis

\begin{tabular}{|c|c|c|c|c|c|}
\hline Proposal & Date of initiation & Date of decision & Procedure & Threshold & Outcome \\
\hline End-of-life vehicles Com (97) 358 & 09-07-1997 & $20-07-2000$ & Codecision & $\mathrm{QMV}^{\mathrm{a}}$ & Adopted \\
\hline Taxation savings income Com (98) 295 & $20-5-1998$ & $26-11-2000$ & Consultation & Unanimity & Not adopted ${ }^{\mathrm{b}}$ \\
\hline Taxation of cigarettes Com (98) 320 & $15-5-1998$ & 29-07-1999 & Consultation & Unanimity & Adopted \\
\hline Supervision e-money Com (98) 461 & 21-09-1998 & $16-06-2000$ & Codecision & Unanimity & Adopted \\
\hline Notification agreements Com (98) 546 & 30-09-1998 & 10-06-1999 & Consultation & QMV & Adopted \\
\hline E-commerce Com (98) 586 & 18-11-1998 & $05-05-2000$ & Codecision & QMV & Adopted \\
\hline TSE Com (98) 623 & 18-11-1998 & $13-02-2001$ & Codecision & QMV & Adopted \\
\hline Vet. medical products Com (99) 130 & 18-03-1999 & 15-06-1999 & Consultation & QMV & Adopted \\
\hline Establishment Eurodac Com (99) 260 & 26-05-1999 & $11-12-2000$ & Consultation & Unanimity & Adopted \\
\hline Atlantic Zone fishing Com (99) 345 & 12-07-1999 & 16-12-1999 & Consultation & QMV & Adopted \\
\hline Comm. Matters Com (99) 348 & 14-07-1999 & $22-12-2000$ & Consultation & QMV & Adopted \\
\hline Dialogue fisheries Com (99) 382 & 22-07-1999 & $27-03-2000$ & Consultation & QMV & Adopted \\
\hline Bovine animals/swine Com (99) 456 & 25-10-1999 & $17-04-2000$ & Codecision & QMV & Adopted \\
\hline Equal treatment Com (99) 565-7 & 25-11-1999 & $27-11-2000 / 29-06-2000^{\mathrm{c}}$ & Consultation & Unanimity & Adopted \\
\hline Toys made of PVC Com (99) 577 & 10-11-1999 & - & Codecision & QMV & Pending $^{\mathrm{d}}$ \\
\hline
\end{tabular}

${ }^{\mathrm{a}} \mathrm{QMV}=$ qualified majority vote.

${ }^{\mathrm{b}}$ The Commission withdrew this proposal after lengthy discussions within the European Council. A new and more timid proposal was agreed upon in January 2003 (Schneider and Baltz, 2003a).

${ }^{c}$ Proposals (99) 565 and (99) 566 were decided upon on 27 November, 2000, and (99) 567 on 29 June of the same year.

${ }^{\mathrm{d}}$ The Council just recently reached an agreement on a common position on 24 September, 2004. 
position. Previous publications studied in detail the gains and losses of the actors during the domestic pre-negotiations (e.g. Schneider and Baltz, 2003a, b; Baltz et al., 2004). ${ }^{6}$ The dependent variable is accordingly dichotomous, with 1 standing for a move away from the initial position and 0 representing a case in which the negotiation position is equal to the initial proposal of the lead ministry. ${ }^{7}$ Note that we compare the probability of a position change at the issue rather than the proposal level of analysis. As we might observe similar behaviour across the issues within a legislative proposal, we control for this clustering effect through the calculation of a fixed-effect model.

We operationalized the explanatory variables in the following way. The first predictor variable - the variance of the stakeholder positions - is simply measured through the standard deviation of the bliss points of all stakeholders that became active on an issue. Polarization of stakeholders is based on the Hirschman-Herfindahl concentration index. It receives the maximal value if the concentration is low, meaning that the same proportion of stakeholders takes all quartiles which contain real positions on the issue scale. The minimal value represents the case that all stakeholders are in the same quartile. To assess the effect of distance of the actors towards the Commission proposal, we introduced a variable that pits the most EU-critical country in the dataset, Great Britain, against the three other countries. We call this dummy variable scepticism; it is accordingly coded 0 if it is a proposal dealt with in Great Britain and 1 if it is one of the other member states.

If parliament or parties represented in the legislature took a position, Parliament is coded as 1, 0 otherwise. We had to use such a crude measurement because these parliamentary actors remain surprisingly often inactive during the negotiations. We used the expert assessments for our construction of the power variables. Power of the lead ministry measures the power that the experts attributed to other governmental stakeholders than the ministry in charge; 0 stands for no power, 100 for maximal power. Relative power of non-state actors is the mean power of the non-state actors divided through the mean power of non-state actors plus the mean power of the government actors. Outside lobbying amounts to 1 if an interest group used voice strategies during the prenegotiation process through the usage of media campaigns and other means of public pressure. It is 0 if the expert was not able to report such behaviour. We used an interaction variable between the presence of outside lobbying and the power of the interest groups engaging into it in some tests. Like vs opposite bias was operationalized in a stepwise way. We first subtracted the positive mean value of the positions of all interest groups active on an issue from the initial position of the lead ministry, that is, bias $=\mid$ mean pos $-i p \mid$. This yields higher values for situations with like than for those with perfect opposite bias. The variable takes a value of 0 if the same number of interest groups has preferences on opposite sides of the lead ministry and if the absolute distances 
to the lead ministry cancel each other out. Second, since we expect the influence of like bias to be negatively curvilinear, we centre the variable along its mean and squared it, replacing all positive values through their corresponding negative ones.

\section{The Interplay between State and Social Actors in Domestic EU-Policy Making}

Current theories of public policy making disagree whether or not state or societal actors dominate EU policy making. We show in this section that the lead ministry most often gets its way in the domestic pre-negotiations on legislative proposals that the European Commission has submitted. Yet, as our descriptive and statistical analysis shows, there are important exceptions to this trend.

The evidence presented in Table 2 demonstrates that interest groups and government ministries rather than parties and parliaments are key actors in the domestic pre-negotiations on legislative proposals. To illustrate the activity level of the different domestic stakeholders, we have classified them into different actor groups. Government actors include the lead ministry who is in charge of a piece of legislation and the other ministries that might become active during the pre-negotiations. We summarized parties and parliamentary actors within one category and distinguished in two ways between types of interest groups. First, we classified an interest group as 'general' if it became active on more than $40 \%$ of the issues discussed within a country. The alternative is the category 'special interest group'. As most proposals activated the cleavage between producer and consumer interests, we added a distinction between 'general' and 'specialized' producer and consumer interest groups. Table 2 lists the actor groups that we have constructed in this way. It shows how often they became active, how much their positions varied at the average and how far the positions were away from the original proposal of the ministry in charge of the negotiations.

One feature all four states share is the relative unimportance of parties and the parliament as actors in the preparatory stage of EU legislation. While the actors from the executive branch and the interest groups became frequently active, parliaments and parties only took a position on approximately onethird of all issues. Interestingly, not all ministries and government departments have the same chance of receiving the mandate to lead the domestic prenegotiations. Of the 50 ministries in charge of the 15 legislative proposals, four departments shared the great bulk of assignments: Agriculture (11), Finance (10), Economy/Trade and Industry (9) and Justice (7). Most often functionally similar ministries are entitled to lead the domestic pre-negotiations. 
Table 2 Activity and heterogenity of actor groups in the domestic pre-negotiations of EU-legislation in four member states

\begin{tabular}{|c|c|c|c|c|c|c|c|c|c|c|c|c|c|c|c|}
\hline \multirow[t]{2}{*}{ Actors } & \multicolumn{5}{|c|}{ Number of positions $\mathrm{a}^{\mathrm{a}}$} & \multicolumn{5}{|c|}{ Standard deviation of positions } & \multicolumn{5}{|c|}{ Mean $|p o s-i p|^{\mathrm{b}}$} \\
\hline & $D$ & FIN & $N L$ & $U K$ & $\varnothing$ & $D$ & $F I N$ & $N L$ & $U K$ & $\varnothing$ & $D$ & FIN & $N L$ & $U K$ & $\varnothing$ \\
\hline Lead $n$ & 27 & 24 & 39 & 27 & 29 & 34.6 & 37.1 & 59.4 & 44.1 & 41.6 & $3.7^{\mathrm{c}}(9.3)$ & $0.0(0.0)$ & $0.0(0.0)$ & $0.0(0.0)$ & $0.9(4.7)$ \\
\hline Other ministries & 39 & 17 & 40 & 14 & 28 & 35.1 & 43.5 & 35.2 & 46.7 & 38.8 & $15.1(21.8) 2$ & $21.2(29.1)$ & $29.1(35.7)$ & $9.6(26.9) 2$ & $20.5(29.7)$ \\
\hline Parliament/parties & 12 & 10 & 7 & 8 & 9 & 43.5 & 39.2 & 43.4 & 51.8 & 43.6 & $34.2(32.0)$ & $8.0(15.5)$ & $75.7(31.0) 1$ & $12.5(35.4) ?$ & $30.3(37.3)$ \\
\hline Specialized consumer & s 12 & 18 & 9 & 12 & 13 & 40.2 & 47.9 & 40.9 & 49.8 & 46.0 & $46.7(35.2) 3$ & $33.9(40.6)$ & $65.6(38.1) 5$ & $53.3(40.5)$ & $47.1(39.5)$ \\
\hline General consumer interest $\xi$ & 21 & - & 10 & 5 & 9 & 33.2 & - & 38.9 & 13.4 & 36.7 & $20.5(26.5)$ & - & $42.5(24.9) 3$ & 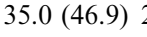 & $28.6(30.2)$ \\
\hline Specialized producer interest groups & 49 & 44 & 36 & 25 & 39 & 42.0 & 48.7 & 37.8 & 43.1 & 43.4 & $63.6(32.6) 3$ & $33.6(33.6)$ & $56.1(34.6) 3$ & $37.2(39.9)$ & $49.0(36.7)$ \\
\hline General producer interest groups & 28 & 13 & 44 & 24 & 27 & 39.7 & 30.0 & 35.5 & 42.9 & 39.0 & $41.1(28.9) 5$ & $59.2(26.9)$ & $84.7(23.6) 2$ & $20.6(34.8)$ & $56.3(38.0)$ \\
\hline
\end{tabular}

${ }^{a}$ The number refers to how often a specific actor group has become active on the issues in the specific country.

bStandard deviation in parentheses.

${ }^{\mathrm{c}}$ The task to be the lead ministry was shared in two occasions in Germany. 
We found in line with Olson (1965) and Schneider and Baltz (2003a, b) that specialized interest groups are frequently active. This underlines that European integration is nowadays not just the preoccupation of a relatively narrow elite, but involves occasional actors who have a specific interest in a proposal. Table 2 also shows that the average distance of the actor groups varies considerably among the actor groups. Government actors, the parliament and parties are at the average closer to the initial position than the private actors. Within this group, specialized consumer interest groups are further away from the initial proposal than general consumer interest groups. The opposite is the case for the groups that are supposed to advance producer interests.

The relative importance of specialized interest groups is a first indication that the power of the lead ministry might be limited in some cases under consideration. Table 3 provides some descriptive evidence on how large the discretionary power of the lead ministry is. We first show in the second column how extreme the position is with respect to the rest of the players as they are represented by the median player. ${ }^{8}$ The third column then demonstrates how much the lead ministry had to give in. Note that this analysis refers to the proposal rather than to the issue-level of analysis. We have calculated averages if there was more than one issue within a proposal.

The analysis presented in Table 3 shows that the discretionary power granted to the lead ministry differs considerably across the four states under examination. The Dutch agenda setter takes at the average the most radical position, followed by Germany. Interestingly, these ministries do not have to give in to a disproportional extent. On the contrary, the Dutch lead ministries yield at the average less than their Finnish or German counterparts. This becomes clear if we compare the radicalism measure with the utility loss. In the Dutch case, the ratio between the two averaged indicators is $3.2(40.4 / 12.6)$; in Germany and Finland, it amounts to 1.6 (28.3/17.3 and 21.4/13.4). Only the British lead ministry with a ratio of $19.1 / 5.61(=3.4)$ is similarly successful in shielding its initial proposal against the wishes of domestic stakeholders.

Similar results can be obtained if we simply look in a dichotomous fashion at the possibility that the lead ministry had to give in or not. In Germany, the lead ministries possess the smallest leeway because they experienced a loss in 20 out of 24 cases. In the other states, the discretionary power is much larger. The relative number of position shifts amounts to 17 out of 39 and in Finland to 10 out of 24 cases. The extremeness of the Commission proposal with respect to the stakeholder positions explains that the lead ministry in the United Kingdom only experienced a utility loss on three of the 21 issues examined here.

There is additionally also variance across the proposals under examination. While the end of life-vehicle directive was disputed in Germany, it did not cause a controversy in the Netherlands because the proposed European 


\begin{tabular}{|c|c|c|c|c|c|c|c|c|c|c|}
\hline \multirow[t]{2}{*}{ Proposal } & \multicolumn{5}{|c|}{ Distance of position to median $=\mid i p-$ medpos $\mid$} & \multicolumn{5}{|c|}{ Loss of the lead ministry $=|i p-n p|$} \\
\hline & $D$ & Fin & $N L$ & $G B$ & $\varnothing$ & $D$ & Fin & $N L$ & $G B$ & $\varnothing$ \\
\hline End-of-life vehicles Com (97) 358 & $50.0(0.0)$ & $0(0.0)$ & $70(0.0)$ & $0(0.0)$ & $30(0.0)$ & $10(0.0)$ & $0(0.0)$ & $0(0.0)$ & $0(0.0)$ & $3.33(0.0)$ \\
\hline $\begin{array}{l}\text { Taxation on savings income } \\
\text { Com (98) } 295\end{array}$ & $46.66(4.77)$ & $66.66(28.86)$ & $33.33(20.81)$ & $0(0.0)$ & $36.66(13.61)$ & $10(8.45)$ & $34(14.04)$ & $3(6.32)$ & $0(0.0)$ & $11.75(10.60)$ \\
\hline $\begin{array}{l}\text { Taxation of cigarettes } \\
\text { Com (98) } 320\end{array}$ & $50(70.71)$ & $50(0.0)$ & $25(35.35)$ & $0(0.0)$ & $31.25(26.51)$ & $7.5(7.90)$ & $0(0.0)$ & $12.5(13.36)$ & $0(0.0)$ & $5(11.94)$ \\
\hline $\begin{array}{l}\text { Supervision e-money } \\
\text { Com (98) } 461\end{array}$ & $0(0.0)$ & $20(26.45)$ & $28.33(25.65)$ & - & $12.08(17.36)$ & $20(0.0)$ & $26(18.37)$ & $10(14.63)$ & - & $18.66(11.0)$ \\
\hline $\begin{array}{l}\text { Notification agreements } \\
\text { Com (98) } 546\end{array}$ & $18.33(10.40)$ & $33.33(28.86)$ & $81.4(15.40)$ & 10 & $35.76(17.20)$ & $10(0.0)$ & $17.39(11.76)$ & $4.57(8.52)$ & $12.5(12.82)$ & $11.11(8.27)$ \\
\hline $\begin{array}{l}\text { Legal aspects of e-commerce } \\
\text { Com (98) } 586\end{array}$ & $3.33(5.77)$ & $37.5(35.0)$ & $35(21.21)$ & $0(0.0)$ & $18.95(15.49)$ & $13.33(4.76)$ & $7.24(3.91)$ & $22.5(7.78)$ & $39.28(21.29)$ & $20.58(9.43)$ \\
\hline $\begin{array}{l}\text { Prevention/ Control of TSE } \\
\text { Com (98) } 623\end{array}$ & $60(0.0)$ & $0(0.0)$ & $56.33(1.15)$ & - & $38.77(0.38)$ & $40(0.0)$ & $0(0.0)$ & $26.66(4.85)$ & - & $22.22(1.61)$ \\
\hline $\begin{array}{l}\text { Limits vet. medical products } \\
\text { Com (99) } 130\end{array}$ & - & - & $12.5(25.0)$ & - & $12.5(25.0)$ & - & - & $12.5(13.17)$ & - & 12.5 \\
\hline $\begin{array}{l}\text { North-East Atlantic Zone fishing } \\
\text { Com (99) } 345\end{array}$ & - & - & $50(0.0)$ & - & $50(0.0)$ & - & - & $20(0.0)$ & - & $20(0.0)$ \\
\hline $\begin{array}{l}\text { Jurisdiction comm. matters } \\
\text { Com (99) } 348\end{array}$ & $11.66(7.52)$ & $0(0.0)$ & $28.33(25.65)$ & $0(0.0)$ & $9.99(8.29)$ & $23.33(4.78)$ & $0(0.0)$ & $25.41(5.41)$ & $0(0.0)$ & $12.18(2.54)$ \\
\hline $\begin{array}{l}\text { Dialogue common fisheries } \\
\text { Com (99) } 382\end{array}$ & $100(0.0)$ & $22.5(3.53)$ & $85(21.21)$ & $100(0.0)$ & $76.87(6.18)$ & $64(12.65)$ & $30(0.0)$ & $0(0.0)$ & $0(0.0)$ & $23.5(3.16)$ \\
\hline $\begin{array}{l}\text { Bovine animals/swine } \\
\text { Com (99) } 456\end{array}$ & - & - & $70(0.0)$ & $0(0.0)$ & $35(0.0)$ & - & - & $0(0.0)$ & $0(0.0)$ & $0(0.0)$ \\
\hline $\begin{array}{l}\text { Equal treatment employment } \\
\text { Com (99) 565-7 }\end{array}$ & $0(0.0)$ & $5(0.0)$ & $1.66(2.88)$ & $0(0.0)$ & $1.66(0.72)$ & $0(0.0)$ & 32.5 (29.39) & $10(7.22)$ & $0(0.0)$ & $10.62(9.15)$ \\
\hline Toys made of PVC Com (99) 577 & $0(0.0)$ & $0(0.0)$ & $26(29.46)$ & $0(0.0)$ & $6.5(7.36)$ & $10(0.0)$ & $0(0.0)$ & $22.60(17.37)$ & $10(0.0)$ & $10.65(4.34)$ \\
\hline Mean & 28.33 & 21.36 & 40.41 & 19.09 & 28.69 & 17.34 & 13.37 & 12.62 & 5.61 & 12.57 \\
\hline
\end{tabular}

Notes: Numbers are mean values across the issues for each proposal. Standard deviation in parentheses.

ip $=$ initial position of the lead ministry prior to domestic negotiations.

$\mathrm{np}=$ national position of the lead ministry after domestic negotiations.

medpos $=$ position of the median actor. 
legislation was largely a copy of the Dutch regulation. The proposed ecommerce directive, with which the European Commission entered a new and largely unknown field of legislation, led to policy shifts of the lead ministry in all four member states.

We will now turn to the macro-quantitative evidence and analyse whether we can explain the shifts in the negotiation positions through the three models presented in the theoretical section of this study. In Table 4, the first statistical model estimates the likelihood of a position shift by the lead ministry as a consequence of the preference distribution that an issue generated. The second model shows how opposition from other government agencies or parliamentary actors forces a government to give in, and the third model considers the impact that private actors and especially specialized interest groups have on the outcome. We add a fourth model as a synthesis of the three contending views on bureaucratic discretion in domestic pre-negotiations. ${ }^{9}$ The Tobit model controls whether the regression results depend on the dichotomous way in which we operationalized the outcome variable. It relies accordingly on the continuous measure of the dependent variable. Tobit regressions also take the truncation of the dependent variable into account.

The regression results only lend support to some of the hypotheses that we introduced in the theoretical section. The overall conflict a proposal generated does not entice the lead ministry to change its position. The second conflict measure, the polarization variable, by contrast, exerts a strong influence. ${ }^{10}$ This indicates that a lead ministry is more likely to give in if preferences are not concentrated but distributed bi- or multimodally. This relationship supports the hypothesis of Esteban and Ray (1999) that polarized preference configurations are more conflict-prone.

As we were able to suspect from the descriptive statistics, the presence of a parliamentary player or other powerful governmental actors does not influence significantly the likelihood that the agenda setter gives in. Lead ministries are only forced to yield if they face powerful non-state actors. Models 3 and 4 exhibit this trend. This means practically that interest groups are the only systematic force that limits the sway of governments in domestic prenegotiations. This is insofar problematic as they most often represent special rather than public interests. Outside lobbying has a negative impact on the willingness of the lead ministry to change its position. This means that this strategy is largely counterproductive. As expected, it is only effective if it is accompanied by pressure attempts from powerful interest groups. ${ }^{11}$ The statistical analysis also corroborates the game-theoretical results of Grossman and Helpman (2001) and shows that a 'like bias' preference distribution of the interest groups makes a difference. Unified interest groups are thus, in other words, more powerful than ideologically divided ones. The squared term 
Table 4 Regression models on the influence of proposal characteristics on the shift of the lead ministry

\begin{tabular}{|c|c|c|c|c|c|}
\hline & (1) (Logit) & (2) (Logit) & (3) (Logit) & (4) (Logit) & (4) (Tobit) \\
\hline \multicolumn{6}{|l|}{ Overall conflict } \\
\hline Variance of preferences & $-0.04 * *(0.02)$ & & & $-0.02(0.02)$ & $-0.16(0.26)$ \\
\hline Polarization of stakeholders & $3.81 * *(1.60)$ & & & $3.93 * *(1.72)$ & $37.79 * *(16.25)$ \\
\hline \multicolumn{6}{|l|}{ State conflict model } \\
\hline Relative power of state actors & & $0.46(0.97)$ & & $0.67(0.85)$ & $5.00(13.28)$ \\
\hline Parliament & & $0.39(0.52)$ & & $0.38(0.53)$ & $3.23(5.39)$ \\
\hline \multicolumn{6}{|l|}{ Interest group conflict model } \\
\hline Relative power of non-state actors & & & $3.36^{* *}(1.61)$ & $3.97 * * *(1.38)$ & $48.27 * *(23.03)$ \\
\hline Outside lobbying & & & $-0.42(0.38)$ & $-0.75 * * *(0.25)$ & $-14.46^{* *}(6.03)$ \\
\hline Like Bias squared & & & $0.0003 * *(0.0001)$ & $0.0002 *(0.0001)$ & $0.001(0.002)$ \\
\hline Skepticism & $2.05^{* * *}(0.71)$ & $2.28 * * *(0.73)$ & $2.61 * * *(0.63)$ & $2.02 * * *(0.64)$ & $22.53 * * *(8.40)$ \\
\hline Constant & $-1.41(1.42)$ & $-2.08(1.07)$ & $-2.54 * * *(0.74)$ & $-3.59 * * *(1.18)$ & $-40.48 * *(17.87)$ \\
\hline Wald $\chi^{2} /$ LR $\chi^{2}$ & $56.25^{* * *}$ & $31.47^{* * *}$ & $32.29^{* * *}$ & $127.84^{* * *}$ & $30.24^{* * *}$ \\
\hline Log-likelihood (LL(0)) & $-60.49(-74.39)$ & $-64.79(-74.39)$ & $-60.90(-74.39)$ & $-57.03(-74.39)$ & -289.17 \\
\hline$N$ & 108 & 108 & 108 & 108 & 108 \\
\hline Pseudo $R^{2}$ & 0.18 & 0.13 & 0.18 & 0.23 & 0.05 \\
\hline$\%$ correctly classified & 69.44 & 68.52 & 74.07 & 72.22 & - \\
\hline
\end{tabular}

Note: Entries are regression parameters. Standard deviation is in parentheses. The Tobit Model has 49 left-censored observations at difipnp $=0$ and 2 right-censored observations at difipnp $\geqslant 60$, which is the dependent variable, the utility loss of the leading ministry, see also Table 3 ; this is the difference (dif) between the initial position of the leading ministry(ip) and its final national position (np). 
implies, however, that the influence attempts of the private actors are less successful if their preferences are extreme.

As the results of the full model 4 reveal, only the variables from the overall conflict model and especially the interest group conflict model contribute significantly to the explanation of the shift of the initial position of the lead ministry. This finding supports results we established in earlier publications where we analysed only the influence of interest groups, not controlling for all other active stakeholders (Schneider and Baltz, 2003a, b; Baltz et al., 2004). The results reported for the Tobit regression indicate that the operationalization of the dependent variable is not of major importance. All regression parameters have the same sign and almost all retain their significance.

\section{Comparative Case Study}

We would like to illustrate our findings with a comparative case study on the proposal by the European Commission to ban six dangerous substances (socalled phthalates-softeners) for the use in soft PVC toys that toddlers can put into their mouth. ${ }^{12}$ A second goal was that these playthings shall be labelled with a warning on the toy and the packaging. One special feature of the discussions on this legislative proposal was the lack of scientific consensus on which phthalates can possibly replace the toxic ones.

The Commission initiated this proposal in 1999 after Greenpeace had launched a campaign that alarmed parents and legislators against 'toxic toys' (Greenpeace, 1997). According to Wernicke (1999), the intense lobbying of the toy industry had prevented the Commission from becoming active for a long time although half the EU member states had voluntarily introduced nationwide bans. The intense lobbying from Greenpeace led to a split between two directorates - the Internal Market Directorate and the Health and Consumer Protection Directorate - and a legislative delay at the European level. One important feature of this proposal was the intensive pressure that Greenpeace exerted both at the supranational and the national level (Bachmann, 1999). Yet, the proposal of the European Commission remained controversial within the EU institutions and also led in some member states to intensive discussions. The national decision-making processes are insofar special as the lead ministries were by and large able to withstand pressure from interest groups and other stakeholders.

\section{Finland}

Stakeholders disagreed over three questions in the Scandinavian member state. A first bone of contention was whether the prohibition of six phthalates was 
18

far-reaching enough. The consumer organizations opted for a comprehensive ban, while most other domestic actors opposed this radical option. A second issue related to the labelling question. The interest groups except Greenpeace and the state actors reached the consensus that the scientific evidence was not yet conclusive enough for allowing the banning of all toys containing phthalates. The third dispute again pitted Greenpeace against the rest of the stakeholders. The NGO would have liked to commission research on the migration behaviour of phthalates and thus the potential diffusion out of toys that young children were sucking or teething. Almost all interest groups agreed with the state actors that such tests were not necessary.

We conducted a multidimensional scaling analysis to summarize the preference distributions over the three issues in a two-dimensional policy space. Figure 1 shows that the level of controversy was not particularly high. Interestingly, the more specific producer and consumer interest groups are quite close to the national position in comparison to the more general consumer interest groups. Because stakeholders were only minimally polarized, the lead ministry was able to push its initial position successfully through the national deliberation. The government actor also profited from the division among the interest groups on this question. The preferences were accordingly

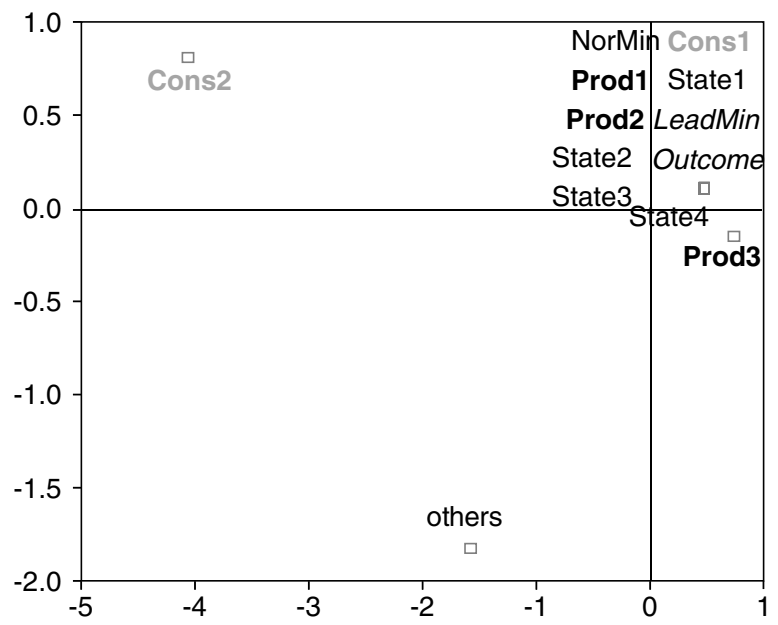

Figure 1 MDS plot stakeholder positions in Finland on proposal COM 99/577 (Stress $=0.000$ ). Note: LeadMin = Initial Position of Lead Ministry: Ministry of Social Affairs and Health; NorMin $=($ Ministry of Trade and Industry; State1 $=$ Finnish Consumer Agency; State $2=$ Finnish Environment Institute; State $3==$ National Product Control Agency; State $4=$ State Technical Research Centre; Cons1 = trade unions; Cons $2=$ Greenpeace European Unit Brussels; Prod $1=$ Chemical Industry Federation; Prod $2=$ Plastic Industry Federation; Prod $3=$ toy importers (no domestic toy industry in Finnland); Others $=$ Nordic Dimension (co-ordination of policy with Sweden and DK); Outcome = national position of the lead ministry. 
similar to a situation of opposite rather than like bias. The attempted coordination of the policy positions of the Scandinavian countries through the so-called Nordic dimension had also no effect on the national position.

\section{Germany}

This Commission proposal activated 10 domestic stakeholders, namely the Länder, the Associations of Commerce, trade associations and consumer organizations as well as several ministries and the Bundestag. The Ministry of Health led the domestic pre-negotiations.

The proposal generated intensive discussions at three levels. A first controversial issue was the number of phthalates that the new legislation should cover. This question pitted the producer organizations against the rest of the stakeholders. While the ministries, the Länder, the national parliament and the environmental groups preferred to ban all phthalates, the interest groups of the industry supported the more timid proposal of the Commission. The final national position of the lead ministry on this issue was a compromise between the two positions insofar as the German negotiation team had to opt for only six phthalates to be excluded from the total ban. A second issue concerned the risk that kids suck on toys, which are - of course - not intended for this purpose. One group of stakeholders wanted the legislation to cover such playthings if they are targeted at children under the age of 3 . The producer association, conversely, was against an inclusion. The third issue related to toys that are explicitly made to be taken into the mouth. One group of stakeholders supported a regulation for toys that are designed for children under 3 years. Although the producers again completely rejected this proposal, the decision-making processes resulted in the adaptation of the consumerfriendly version.

Figure $2^{13}$ shows that national decision makers were highly polarized and that there was a tacit coalition between consumer interests and

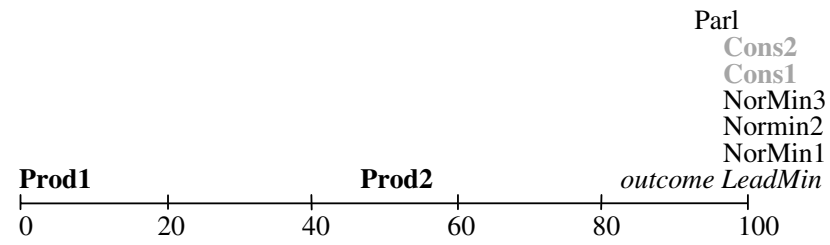

Figure 2 Relative actor positions in Germany on proposal Com 99/577. Note: LeadMin= Initial Position of the lead ministry = Ministry of Health; NorMin $1=$ normal ministry (Ministry of Labour and Social Affairs); NorMin2=normal ministry (Ministry of Environment); NorMin3=normal ministry (Ministry of Economics); Cons1=Greenpeace; Cons2= consumer organizations; $\operatorname{Parl}=$ Parliament; $\operatorname{Prod} 1=$ producers association; $\operatorname{Prod} 2=$ trade associations; outcome $=$ national position of the lead ministry. 
government actors, a constellation which is rare in German pre-negotiations (Schneider and Baltz, 2003a, b). The distribution of preferences is peculiar insofar as the lead ministry itself occupied one of the two extreme positions on the issue scale. As only one of the four active groups is located far away from the ministry, it becomes clear why the position shift was marginal.

\section{Netherlands}

Greenpeace was in the Netherlands like in Finland a key player. The NGO started a public campaign against the use of all 30 phthalates in toys. This position had the backing of the Ministry of Environment. This alliance found, however, the opposition of all producer interest groups, the Parliament and the Ministry of Health, which was the lead ministry for this proposal. These actors preferred the minimal solution to ban only phthalates in toys for children between 0 and 3 years. Other public interest organizations issued a more moderate position than Greenpeace.

Two rather heterogeneous groups formed in the dispute on whether or not a ban should follow the publication of unambiguous scientific evidence that toys containing phthalates pose risks. The toy industry and the Ministry of Health favoured the position that the available data were no proof of the danger of phthalates. They recommended further tests, while Greenpeace together with the Ministry on Environment called for immediate action. A third controversy arose about the question of whether or not tests should be conducted on the migration behaviour of phtalates. The coalition structure mirrored the distribution of preferences on the second issue, with the toy industry and the Ministry of Health opposing tests and Greenpeace and the Ministry of Environment calling for them.

Figure 3 visualizes the policy space in which these discussions took place. The MDS plot shows the conflict structure especially between the lead ministry and the various interest groups. This example confirms the finding that the higher the polarization of the stakeholders, the more likely is a shift of the bargaining position of the lead ministry. The relative power of interest groups in comparison to the state actors is also an important factor in this case to explain the significant losses of the lead ministry. The private actors that became active had about the same average power as the government actors. Their preferences are distributed in an opposite-biased way, so the lead ministry was in a relatively comfortable position and only made concessions on one dimension. 


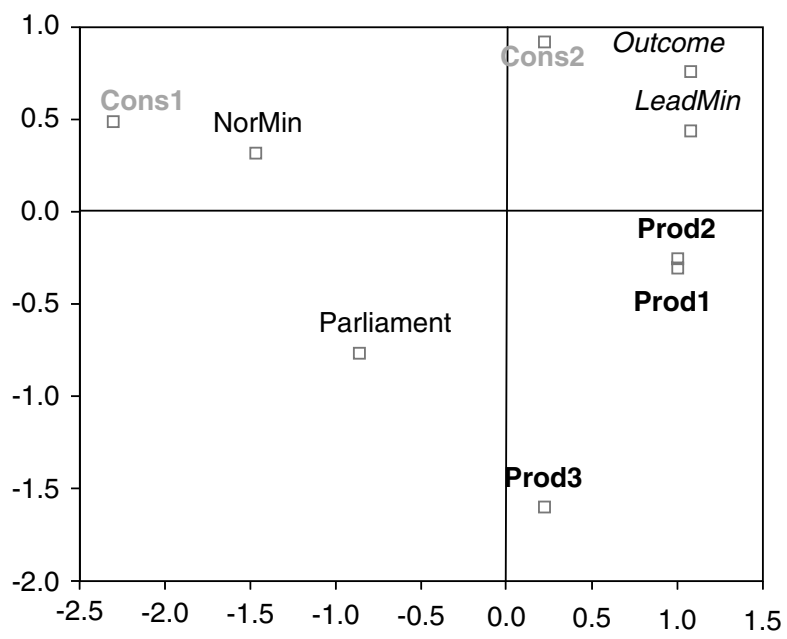

Figure 3 MDS plot of positions of stakeholders in the Netherlands on proposal COM 99/577 (stress $=0.005$ ). Note: LeadMin = Initial Position of the lead ministry: Ministry of Health; NorMin $=$ Ministry of Environment; Parliament $=$ Position of Parliament; Prod $1=$ Association of toy trade; Prod $2=$ EU organisation of toy manufacturers; Prod $3=$ PVC industry; Cons $1=$ GreenGreenpeace Cons $2=$ Consumer organizations; Outcome $=$ National Position of the lead ministry.

\section{United Kingdom}

The proposal of the European Commission was highly controversial in the United Kingdom. Because the envisaged six phthalates were no longer in use in the British toy production, this key issue of the legislative proposal did, however, not raise controversy. The single issue that was contested dealt with the related question of whether or not the use of the remaining phthalates in toys should be forbidden. Great Britain also deviates from the other countries under examination with respect to the responsible lead ministry. It was the only of the four member state that attributed the responsibility to lead the domestic pre-negotiations to the equivalent of the Ministry of Economics, the Department of Trade and Industry (DTI). ${ }^{14}$

The domestic actors were highly divided on the question of a total ban. Greenpeace and consumer organizations opted for a ban of all 30 phthalates, whereas the plastics and toy industry took the opposite view, arguing that the risk of substitution is minimal and the negative impact of the phthalates limited. The industry also called for further scientific tests on the migration behaviour of phthalates. The World Wildlife Fund took a moderate position and called for a label on such products, which could be put into the mouth of children. The lead ministry was more inclined to the position of the producer 


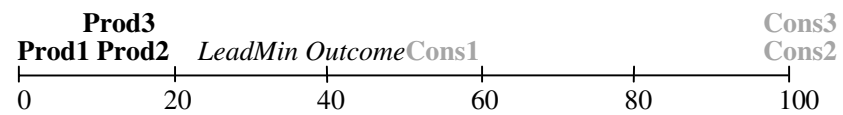

Figure 4 Relative actor positions in Great Britain on proposal Com 99/577. Note: LeadMin = Initial position of the Lead Ministry: Industry Division \& Safety of Toys and Childcare Division of the Department of Trade and Industry; Prod $1=$ Toy Industry; Prod2=Childcare article Industry; Prod3 = Plastic Indutry; Cons $1=$ World Wildlife Fund; Cons2 = ConConsumer Organizations; Cons3= Greenpeace; Outcome = National Position of Lead Ministry.

interest groups. It favoured different and more levels of testing. It had finally to move its final national bargaining position slightly closer to the position of the consumer groups although the shift remained marginal.

Figure 4 illustrates that the level of conflict among the stakeholders was considerable. The high polarization lets us expect that the lead ministry is forced to shift its bargaining position. This effect of the polarization of preferences is reduced by the fact that the distribution of preferences among the active interest groups reveals a situation with opposite bias towards the position of the lead ministry, which explains the only minor loss of the lead ministry. The power that was attributed to the interest groups is approximately as strong as that of the lead ministry, which is the sole government actor. The direction of the shift can be largely explained through the divergence in the power that the contending interest groups possess. While the producer interest groups, backed by the lead ministry, had only a mean value of about 20 on the 100-point power scale, the mean power of the consumer interest groups lies at about 70. It should also be noted that we only observed position shifts in the United Kingdom if the task to lead the negotiations was attributed to the Department of Trade and Industry. The outside lobbying into which Greenpeace as a powerful lobby group engaged was at least partly successful as the lead ministry moved away from a purely producer-friendly position. ${ }^{15}$

\section{Decision making at the EU level}

All other member states equally welcomed the initiative of the Commission, but they disagreed about the way in which the proposal should become effective. Like in three of the four member states under examination, three questions were controversial. Interestingly, the British delegate opted for a more producer-friendly position than it was agreed upon at the national level by just calling for a migration limit for all phthalates in toys and articles. While a ban for all phthalates and migration limits for all the other phthalates was the position of some southern European states, France and Finland, Germany, Austria, Denmark and Sweden called for a comprehensive ban. The second 
issue was partly linked to the first one. Because a complete ban would have rendered a labelling of other toys and children articles superfluous, the consumer-friendly coalition backed by Finland did not support this proposal. The other members rejected this option for opposite reasons, believing that it would amount to a ban. Only the Commission was thus in favour of labelling. The third issue on which a wide range of options were taken concerned the questions of whether or not the fast testing methods for migration limits should be developed or not.

Although the conflict structure at the supranational and at the national level looked similar, finding a compromise was not easy. The proposal went through the first parliamentary reading in 2000; yet, the Council only recently agreed on a Common Position in September 2004. Half a decade after the intensive debate, the problem looks also less urgent since many global and national producers of toys and children article have decided in the meantime to replace PVC containing phthalates in their products.

\section{Conclusion}

This article has analysed how much discretion the lead ministry has in shaping national positions on EU legislation. We have shown that the sway of the national 'Eurocrats' is considerable, but limited through political conflict and the presence of powerful interest groups. This adds to recent research that has analysed how legislatures constrain bureaucratic agents at the purely national level of interaction (e.g. Huber and Shipan, 2002).

The results should caution us against sweeping remarks about the power of bureaucratic elites in the integration process. Although government delegates enjoy some freedom of decision in the Council of Ministers, they cannot completely disregard the wishes of their constituents in these deliberations. The most problematic aspect is that interest groups rather than parliamentary actors and parties build the counterbalance to the governmental actors in many decision-making processes. The prominent role that special interests play aggravates the difficulties in effectively overseeing the governments (Schneider and Baltz, 2003a,b). Only a strengthening of the EU competence of national parties and more transparency in the way decisions are made will probably help in making governments and bureaucrats more accountable for their behaviour in the Council of Ministers and its preparatory agencies.

Our findings also add to the conjecture by Achen (forthcoming) that bargaining is the dominant decision-making mode within the European Union. Although all member states under examination have set up Byzantine coordination mechanisms, the formal rules that guide the interactions between the executive, legislative and private actors are rather unimportant in 
determining the bureaucratic discretion concerning EU-politics. Lead ministries seem to react to the advice and the pressure from other agents if a proposal finds sufficient interest from powerful private actors. If bureaucrats are able to push through their negotiation position, this seems to be a consequence of the wish of other agencies to accept the predominance of the department in charge rather than of cunning agenda setting behaviour.

Previous studies have with the exceptions of Bergman (1997), Pahre (1997) and Martin (2000) left it largely unexplored that European legislation also takes place within a domestic arena. If we want to understand where the preferences of the member states come from, we need to take a closer look at the domestic pre-negotiations. Our comparison of the domestic pre-negotiations is a step in this direction. As our evidence suggests, 'Eurocrats' are 'domesticated' early on in the decision-making process.

\section{Acknowledgements}

A previous version of this paper has been presented at the general conference of the European Consortium for Political Research, Marburg, Germany, 18-21 September, 2003. We thank Simon Hug, Torsten Selck and other participants at this meeting for their comments. Research support by the German Research Foundation is gratefully acknowledged. We thank Anette Arslantas, Ursula Klöpper, Christian Lau, Michael Weltin, and Carl Zimanky for their research assistance. Mark D. Aspinwall, Simon Bulmer, Martin Burch, Tapio Raunio, Bernard Steunenberg, Matti Wiberg, Roger Withaker, and the interviewed experts provided helpful country expertise.

\section{References}

Achen, C.H. (forthcoming) 'Institutional Realism and Bargaining Models', in Thomson, R., Stokman, F., Achen, C. and König, T. (eds.) The European Union Decides, Cambridge: Cambridge University Press.

Alesina, A. and Wacziarg, R. (1999) 'Is Europe going too far?' Carnegie-Rochester Conference Series on Public Policy 51: 1-42.

Bachmann, S. (1999) 'Alles Geschmackssache', Die ZEIT, Nr. 48/1999.

Bailer, S. and Schneider, G. (forthcoming) 'Nash or Schelling? Domestic Constraints in Legislative Bargaining', in Thomson, R., Stokman, F., Achen, C. and König, T. (eds.) The European Union Decides, Cambridge: Cambridge University Press.

Baltz, K., König, T. and Schneider, G. (2005) 'Immer noch ein etatistischer Kontinent: Die Formierung von Positionen zu EU-Verhandlungen in vier Mitgliedstaaten', in R. Eising and B. Kohler-Koch (eds.) Interessenpolitik in Europa, Baden-Baden: Nomos.

Barry, B. (1980) 'Is it better to be powerful or lucky, Part I and Part II', Political Studies 28: 183194, 317-343.

Bergman, T. (1997) 'National Parliaments and EU Affairs Committees - notes on empirical variation and competing explanations', Journal of European Public Policy 4(3): 272-287. 
Beyers, J. (2004) 'Voice and access. Political practices of European interest associations', European Union Politics 5(2): 211-240.

Derlien, H.U. (2000) 'Germany', in H. Kassim, B.G. Peters and V. Wright (eds.) The National Coordination of EU Policy. The Domestic Level, Oxford: Oxford University Press, pp. 54-78.

Esteban, J. and Ray, D. (1999) 'Conflict and distribution', Journal of Economic Theory 87: 379-415.

Franchino, F. and Rahming, A.J. (2003) 'Biased ministers, inefficiency and control in distributive policies: an application to the EC fisheries policy', European Union Politics 4(1): 11-36.

Franchino, F. (2000) 'Control of the Commission's executive functions: uncertainty, conflict and decision rules', European Union Politics 1(1): 59-88.

Frey, B.S. (1997) 'The Public Choice of International Organizations', in D. C. Mueller (ed.) Perspectives on Public Choice, Cambridge: Cambridge University Press, pp. 106-123.

Gallhofer, I.N., Saris, W.E. and Voogt, R. (1994) 'From individual preferences to group decisions in foreign policy decision-making: the Dutch Council of Ministers', European Journal of Political Research 25: 151-170.

Gallhofer, I.N. and Saris, W.E. (1996) Foreign Policy Decision Making: A Qualitative and Quantitative Analysis of Political Argumentation, Westport, CT: Praeger.

Gillingham, J. (2003) European Integration, 1950-2003: Superstate or New Market Economy?, Cambridge: Cambridge University Press.

Greenpeace (1997) Kinderspielzeug aus Weich-PVC: Umweltgift in Kindermund, Hamburg: Greenpeace Hintergrundinformation.

Grossman, G.M. and Helpman, E. (2001) Special Interest Politics, Cambridge, MA: MIT Press.

Hammond, T.H. and Knott, J.H. (1996) 'Who controls the bureaucracy? Presidential power, congressional dominance, legal constraints, and bureaucratic autonomy in a model of multiinstitutional policy-making', Journal of Law, Economics, and Organization 12: 119-166.

Hirschman, A.O. (1970) Exit, Voice, and Loyalty. Responses to Decline in Firms, Organizations, and States, Cambridge, MA: Harvard University Press.

Huber, J.D. and Shipan, C.R. (2002) Deliberate Discretion? The Institutional Foundations of Bureaucratic Autonomy, New York/Cambridge: Cambridge University Press.

Hug, S. and König, T. (2002) 'In view of ratification. Governmental preferences and domestic constraints at the Amsterdam Intergovernmental Conference', International Organization 56(2): 447-476.

Kassim, H., Peters, B.G. and Wright, V. (eds.) (2000) The National Coordination of EU Policy. The Domestic Level, Oxford: Oxford University Press.

Krishna, V. and Morgan, J. (2001) 'A model of expertise', Quarterly Journal of Economics 116: $747-775$.

Martin, L. (2000) Democratic Commitments-Legislatures and International Cooperation, Princeton, NJ: Princeton University Press.

McCubbins, M.D., Noll, R.G. and Weingast, B.R. (1987) 'Administrative procedures as instruments of political control', Journal of Law, Economics and Organization 3(2): 243-277.

Montalvo, J. and Reynal-Querol, M. (2003) 'Ethnic diversity, political systems and conflict', WeltTrends 38(Spring): 38-60.

Moravcsik, A. (1998) The Choice for Europe: Social Purpose and State Power from Messina to Maastricht, Ithaca, NY: Cornell University Press.

Niskanen, W.A. (1971) Bureaucracy and Representative Government, Chicago: Aldine, Atherton.

Olson, M. (1965) The Logic of Collective Action. Public Goods and the Theory of Groups, Cambridge, MA: Harvard University Press.

Pahre, R. (1997) 'Endogenous domestic institutions in two-level games and parliamentary oversight of the European Union', Journal of Conflict Resolution 41(1): 147-174.

Pedersen, T. (2000) 'Denmark', in H. Kassim, B. G. Peters and V. Wright (eds.) The National Co-ordination of EU Policy. The Domestic Level, Oxford: Oxford University Press, pp. 219-234. 
Schneider, G. and Baltz, K. (2003a) 'The power of specialization: how interest groups influence EU-legislation', Rivista di Politica Economica XCIII(January-February): 253-283.

Schneider, G. and Baltz, K. (2003b) 'Am Gängelband der Verbände: Zum Einfluss von Partikularinteressen auf die deutsche EU-Politik', Zeitschrift für Staats- und Europawissenschaften 1(2): 199-219.

Schneider, G., Baltz, K. and Finke, D. (2004a) 'Paying the piper, calling the tune. Interest intermediation in the pre-negotiations of EU legislation, Mimeo, University of Konstanz.

Schneider, G. and Cederman, L.-E. (1994) 'The change of tide in political cooperation: a limited information model of European integration', International Organization 48: 633-662.

Schneider, G., Finke, D. and Bailer, S. (2004b) 'Bargaining power in the European Union. An evaluation of competing game-theoretic models, Mimeo, University of Konstanz.

Siaroff, A. (1999) 'Corporatism in 24 industrial democracies: meaning and measurement', European Journal of Political Research 36: 175-205.

Siedentop, L. (2001) Democracy in Europe, London: Penguin.

Stokman, F.N. and Thomson, R. (2004) 'The winners and losers of European Integration', European Union Politics (Special Issue) 5(1): 5-138.

Thomson, R., Stokman, F., Achen, C. and König, T. (forthcoming) The European Union Decides, Cambridge: Cambridge University Press.

Thurner, P.W. and Stoiber, M. (2002) 'Interministerielle Netzwerke: Formale und informelle Koordinationsstrukturen bei der Vorbereitung der deutschen Verhandlungspositionen zur Regierungskonferenz 1996', Politische Vierteljahresschrift 43(4): 561-605.

Tsebelis, G. (2002) Veto Players. How Political Institutions Work, New York: Sage.

Vaubel, R. (1994) 'The public choice analysis of European integration: a survey', European Journal of Political Economy 10: 227-249.

Wernicke, C. (1999) 'Der Brüsseler Beißring', Die ZEIT, Nr. 48/1999.

Wintrobe, R. (1997) 'Modern Bureaucratic Theory', in D. C. Mueller (ed.) Perspectives on Public Choice, Cambridge: Cambridge University Press, pp. 429-454.

\section{Notes}

1 Using the range of the preference distribution as a more crude measure of conflict, as Tsebelis (2002) suggests, is not suitable for our analysis for reasons of the specific structure of the data set we use. As the positions of the stakeholders are measured on a scale ranging from 0 to 100 , the range would be constant for all issues under examination.

2 Schneider et al. (2004a, b) show that the more polarized actors are, the worse are the predictions of a bargaining model.

3 This larger project is called Decision-Making in the EU (DEU). It evaluates the relative merit of competing game-theoretic models of EU decision making, uniting researchers from the Universities of Groningen, Konstanz, Leiden, Michigan (Ann Arbor), Nijmegen and Turku. Some results of this research group can be found in a special issue of European Union Politics (Stokman and Thomson, 2004) and Thomson et al. (forthcoming).

4 The probability of introducing a bias is minimal because the sample also contains issues in which a proposal that was highly controversial in some countries remained largely undisputed in other ones.

5 All tables and figures in our presentation are based upon and calculated from our NDEUDataset.

6 To check if our results depend on the scale for the dependent variable, we also conducted ordered logit and OLS regressions with the same set of independent variables. The results are 
robust independently from the used regression method but some coefficients lose their significance, which is not the least a consequence of the larger variance on the continuous scale.

7 The alternative would have been to calculate the utility loss over the whole proposal and not only over the different issues. The results that we obtained with this measure are similar and can be obtained from the authors upon request.

8 The calculation of the median position refers to all stakeholders except the lead ministry.

9 The results are not controlling for the number of cases in which the other state or non-state actors issued different positions than the lead ministry. Controlling for it has the consequence that the number of cases becomes very low and that parliament must be excluded as a potential explanatory variable. The results of the more restrictive analysis considering only the subset of cases where the stakeholders really issue different positions from the lead ministry can be obtained from the authors upon request.

10 We tested for multicollinearity through a variance inflation test, which showed that the two preference distribution variables are not seriously correlated. Note also that the Pearson correlation coefficient between the polarization and the variance variable amounts to 0.33 .

11 The parameter of the interaction term of outside lobbying with the relative power of interest groups is positive and significant. We do not report this result in Table 4, however, because of a strong correlation with the outside lobbying variable.

12 This is the European Commission (COM 99/577) proposal to amend the directive 76/769 (EEC) on the approximation of the laws, regulations and administrative provisions of the member states related to restrictions on marketing and use of certain dangerous substances and preparations and to amend Council Directive 88/378 (EEC) concerning the harmonization of the safety of toys.

13 The three-dimensional issue-space could be collapsed into one dimension because the rankings of the actors on all scales coincide.

14 Within the DTI, two different divisions, the Industry Division and the Safety of Toys and Childcare Division had to share the duty as the lead department.

15 This is meant to be only an example and is in no way a 'test' for the results obtained in the statistical analysis because the regression refers to the aggregate issue and not the single actor level. Such an unwarranted conclusion from results of a higher to a lower data level or vice versa would amount to an ecological fallacy. 